\title{
Relationship between HbA1c and Steroid in Initial Attack of Idiopathic Nephrotic Syndrome in Children
}

\author{
Nurun Naher ${ }^{1}$, Sabina Sultana ${ }^{2}$, Abdul Matin ${ }^{3}$ \\ ${ }^{1}$ Senior Registrar, Department of Pediatrics, Apollo Hospitals, Dhaka, Bangladesh; ${ }^{2}$ Senior Consultant (Paediatrics \& \\ Neonatology), Department of Paediatrics, Apollo Hospitals, Dhaka, Bangladesh; ${ }^{3}$ Professor, Shaheed \\ Suhrawardy Medical College, Dhaka, Bangladesh
}

[Received: 21 January 2016; Revised: 6 March 2016; Accepted: 11 December 2016; Published: 1 January 2017]

\begin{abstract}
Background: Blood sugar may be raised as a systemic effect of steroid. Haemoglobin A1c (HbAlc) estimation provides an accurate index of mean concentration of blood glucose during preceding two to three months. Objective: The purpose of the present study was to observe the relationship between oral prednisolone and HbAlc levels in children with 1st attack Nephrotic syndrome. Methods: This case-control study was conducted in the Outpatient department of Apollo Hospitals, Dhaka, Bangladesh from January 2012 to July 2013 for a period of nineteenth (19) months. The nephrotic children with first attack who completed 12 weeks steroid therapy were enrolled as study group. Age and sex matched thirty children with other illness without family history of diabetes regarded as control. HbAlc level was estimated in Nephrotic patient just at the end of their 12 weeks of prednisolone therapy. Results: The mean age of study and control group was $4.56 \pm 1.54$ and 4.90 \pm 1.06 years respectively. Male and female ratios were 1.0:0.76 and 1.0:0.88 in case and control group respectively. Age and sex difference between the groups were not significant. The mean $\mathrm{HbAlc}$ value was $5.00 \pm 0.28$ in case and $4.43 \pm 0.35$ in control group $(\mathrm{p}<0.0001)$. The calculated mean blood sugar level was $99.75 \pm 9.80 \mathrm{mg} / \mathrm{dl}$ and $80.30 \pm 12.48 \mathrm{mg} / \mathrm{dl}$ in case and control group respectively $(\mathrm{p}<0.0001)$. Conclusion: Nephrotic child getting steroid have significantly higher level of $\mathrm{HbAlc}$ then their healthy counterpart though the level is not at diabetic level. [Journal of National Institute of Neurosciences Bangladesh, 2017;3(1): 7-9]
\end{abstract}

Keywords: Haemoglobin A1c; steroid; nephrotic syndrome

Correspondence: Dr. Sabina Sultana, Senior Consultant (Paediatrics \& Neonatology), Department of Paediatrics, Apollo Hospitals, Dhaka, Bangladesh; Email: sultanasm20@yahoo.com; Contact no: +8801715105642

Conflict of Interest: The authors declare that they have no competing interest.

Contributions to Authors: N Naher, S Sultana \& A Matin have involved from protocol preparation up to report writing. All the authors have read and approved the final version of the manuscript.

Funding: This research project was not funded by any group or any institute on.

How to cite this article: Naher N, Sultana S, Matin A. Relationship between HbA1c and Steroid in Initial Attack of Idiopathic Nephrotic Syndrome in Children. J Natl Inst Neurosci Bangladesh, 2017;3(1): 7-9

Copyright: (C2017 Naher et al. Published by Journal of National Institute of Neurosciences Bangladesh. This article is published under the Creative Commons CC BY-NC License (https://creativecommons.org/licenses/by-nc/4.0/). This license permits use, distribution and reproduction in any medium, provided the original work is properly cited, and is not used for commercial purposes.

\section{Introduction}

Initial episode of steroid sensitive nephrotic syndrome usually treated by corticosteroid therapy (prednisone or prednisolone) for at least 12 weeks was recommended by $\mathrm{KDIGO}^{1}$. Glucocorticoids have profound effect on carbohydrate metabolism, stimulating the production of glucose by gluconeogenesis in the liver ${ }^{2}$.

Glycation is the nonenzymatic addition of sugar to amino groups of proteins. While virtually any protein in the body can be glycated, for convenience and ease of obtaining a sample, glycated hemoglobin is measured in the blood obtained from a patient. Blood glucose 
concentrations exhibit wide diurnal fluctuations due to food ingestion, exercise, and other factors. In contrast, the concentration of glycated hemoglobin remains relatively stable with time. This is due to the life span of red blood cells, which is usually $\sim 120$ days. In individuals with a normal erythrocyte life span, glycated hemoglobin is directly proportional to the blood glucose concentration over the preceding 8 to 12 weeks ${ }^{3}$.

Nearly half of the patients treated with Glucocorticoids for more than two weeks developed a deranged glucose metabolism ${ }^{4}$. Some case reports had published associated with Insulin dependent Diabetes Mellitus, Diabetic Ketoacidosis with nephrotic syndrome who are treated with prednisolone ${ }^{5-10}$.

\section{Methodology}

This case-control study was conducted from January 2012 to July'13 in the outpatient department of Apollo Hospitals, Dhaka. Thirty children who were diagnosed as a case of first attack nephrotic syndrome had completed 12 weeks steroid therapy were enrolled in study group as case. Idiopathic nephrotic syndrome was diagnosed in 2 to 7 years age group children with edema, urinalysis reveals $3+$ or $4+$ proteinuria, spot urine protein:creatinine ratio $>2.0$ and urinary protein excretion $>40 \mathrm{mg} / \mathrm{m}^{2} / \mathrm{hr}$, albumin level was $<2.5 \mathrm{~g} / \mathrm{dL}$, and hyperlipidemia without any evidence of macroscopic haematuria or hypertension. Age \& sex matched thirty children who attended for other illnesses were enrolled as control group. Children without family history of diabetes were included in both case \& control group. Infection screening including PPD test was performed to all nephrotic child and if infection screening test as well as PPD test was negative then prednisolone was started. Prednisolone was started at a dose of $60 \mathrm{mg} / \mathrm{m}^{2} /$ day for 6 weeks as daily dose than 40 $\mathrm{mg} / \mathrm{m}^{2} /$ day on alternate day for 6 weeks. After taking ethical clearance from ethical review committee informed consent was obtained from all parents after full explanation of the study purpose. In each children (both in case \& control group), $0.5 \mathrm{ml}$ venous blood samples were collected in tubes containing ethylenediaminetetraacetic acid (EDTA). Blood samples were obtained in the early morning under fasting conditions as a standard procedure. $\mathrm{HbAlc}$ was measured by using HPLC (High Performance Liquid Chromatography). Reference values for healthy control subjects were $5.6 \%$. Analysis was done using the SPSS version 12.0. All values were expressed as a mean with standard deviation. The statistical significance of differences between two groups was evaluated using chi square test and unpaired Student's t-test. The $\mathrm{p}$ value of $<0.05$ levels was regarded as significant.

\section{Results}

Thirty children with nephrotic syndrome completed 12 weeks of steroid therapy were included in the study group $(\mathrm{n}=30)$. Among them 17 children were male and 13 were female, there ratio was 1:0.76 and mean age was $4.56 \pm 1.54$ years. In the control group another 30 children with other illness having no family history of diabetes were included. Among them 16 were male and 14 were female, there ratio was 1:0.88 and mean age was $4.90 \pm 1.06$ years. No significant age and sex differences were found between the study and control groups $(\mathrm{P}=0.324, \mathrm{P}=0.795$ respectively) (Table 1 )

Table 1: Characteristics of the Study Population

\begin{tabular}{lccc}
\hline Variables & $\begin{array}{c}\text { Study group } \\
(\mathbf{n}=\mathbf{3 0})\end{array}$ & $\begin{array}{c}\text { Control group } \\
(\mathbf{n}=\mathbf{3 0})\end{array}$ & p-value \\
\hline Age (Years) & & & \\
mean \pm SD & $4.56 \pm 1.54$ & $4.90 \pm 1.06$ & $0.324^{\mathrm{a}}$ \\
(Range) & $(2.00-7.00)$ & $(3.17-6.58)$ & \\
Sex & & & \\
Male (\%) & $17(56.7)$ & $16(53.3)$ & $0.795^{\mathrm{b}}$ \\
Female (\%) & $13(43.3)$ & $14(46.7)$ & \\
Ratio & $1.0: 0.76$ & $1.0: 0.88$ & \\
\hline
\end{tabular}

'a' Unpaired student ' $\mathrm{t}$ ' test $\&$ ' $\mathrm{b}$ ' chi squarre (x2) test to analyze the data; Level of significance was $<0.05$.

The mean HbAlc level in the study group was $5.00 \pm 0.28$ and in the control group was $4.43 \pm 0.35$ $(\mathrm{P}<0.0001)$. According to calculation, there was higher mean blood sugar level $(99.75 \pm 9.80 \mathrm{mg} / \mathrm{dl})$ in case group than the control group $(80.30 \pm 12.48 \mathrm{mg} / \mathrm{dl})$ $(p<0.0001)($ Table 2).

Table 2: Comparison of HbA1C \& blood glucose level between case (Nephrotic child getting steroid) and control group (Non-nephrotic child) (Mean $\pm \mathrm{SD}$ )

\begin{tabular}{lccc}
\hline Parameter & $\begin{array}{c}\text { Case } \\
(\mathbf{n = 3 0})\end{array}$ & $\begin{array}{c}\text { Control } \\
(\mathbf{n}=\mathbf{3 0})\end{array}$ & P value* \\
\hline HbA1c & $5.00 \pm 0.28$ & $4.43 \pm 0.35$ & 0.0001 \\
Calculated & $99.75 \pm 9.80$ & $80.30 \pm 12.48$ & 0.0001 \\
Blood Glucose & & & \\
$(\mathrm{mg} / \mathrm{dl})$ & & & \\
\hline
\end{tabular}

* Unpaired student' $t$ ' test done to analyze the data; Level of significance was $<0.05$. 


\section{Discussion}

Glucocorticoids are the commonest treatment option for idiopathic nephrotic syndrome with its mechanism of action as an immunosuppressive agent ${ }^{12}$. Glucocorticoids use is associated with many side effects including hyperglycemia, hypertension, pancreatitis, peptic ulcer etc ${ }^{13}$. Forty percent of children with primary renal diseases on glucocorticoids develop deranged glucose metabolism with older age and increased body mass index as risk factors ${ }^{10}$. In about $50 \%$ of cases of steroid induced hyperglycaemia, the hyperglycaemia may persist despite reduction or even discontinuation of the steroid, this is especially so in patients with risk factors for diabetes mellitus ${ }^{10}$.

In this study there is increased glycated hemoglobin level in nephrotic child getting steroid which is supported by Balamurugan et $\mathrm{al}^{14}$. There are limited literatures on the experience and effects of steroids on blood glucose in children with nephrotic syndrome ${ }^{10}$. In this study mean blood glucose level was calculated from HbA1c levels by using a formula in accordance with Rohlfing et $\mathrm{al}^{11}$ (HbA1c x 35.6-77.3= blood sugar $\mathrm{mg} / \mathrm{dl})$. According to this formula, the approximate mean blood glucose concentration was found significantly higher in children with nephrotic syndrome completed 12 weeks of steroid compared to healthy control group which is supported by study done by yucel et al, where they have found higher mean blood glucose concentration in patients receiving inhaled corticosteroid than the healthy control group ${ }^{15}$. There are some limitations of this study. The study sample was small and long term follow up had not done to see the glycaemic control after discontinuation of steroid therapy in nephrotic cases. Therefore, new studies might be necessary to investigate the long term glycaemic control after discontinuation of steroid therapy in nephrotic children treated with steroid.

\section{Conclusion}

In conclusion, increased glycated haemoglobin level is found in nephrotic syndrome patients when compared with controls. Additionally, this study also found that mean blood glucose level was higher in nephrotic syndrome children in compared to healthy children.

\section{References}

1. Lombel RM, Gipson DS, Hodson EM. Kidney Disease: Improving Global Outcomes.Treatment of steroid-sensitive nephrotic syndrome: new guidelines from KDIGO. Pediatr Nephrol 2013;28(3):415-26

2. Ganong WF. Effect of other hormones and exercise on carbohydrate metabolism, In David AB, Jim R, Jean MR. Review of medical physiology,19th ed. Lange Medical Publications, Appleton \& Lange, USA 1999;335-37

3. Sacks DB, Bruns DE, Goldstein DE, Maclaren NK, McDonald JM, Parrott M. Guidelines and recommendations for laboratory analysis in the diagnosis and management of diabetes mellitus. Clin Chem 2002;48:436-72

4. Weir MR, Fink JC. Risk for posttransplant Diabetes mellitus with current immunosuppressive medications. Am J Kidney Dis 1999;34:1-13

5. Agras PI, Kinik ST, Cengiz N, et al. Type 1 diabetes mellitus associated with nephrotic syndrome. J Pediatr Endocrinol Metab 2006;19:1045-8

6. Peces R, Riera JR, López Larrea C, et al. Steroid-responsive relapsing nephrotic syndrome associated with early diabetic glomerulopathy in a child. Nephron 1987;46:78-82

7. Urizar RE, Schwartz A, Top F, Jr, et al. The nephrotic syndrome in children with diabetes mellitus of recent onset. N Engl J Med 1969;281:173-81

8. Gilboa N, Durante D, McIntosh RM, et al. Etiologic variability of nephropathy in juvenile diabetes mellitus. Arch Pathol Lab Med 1979;103:479-82

9. Rego Filho EA, Mello SF, Omuro AM, et al. Simultaneous onset of steroid-sensitive nephrotic syndrome and type 1 diabetes. J Pediatr (Rio J) 2003; 79:557-60

10. Jaja T, Anochie IC, Eke FU. Steroid Induced Diabetic Ketoacidosis (DKA) in a 13 year Old Female with Renal Disorder. Pediatr Therapeut 2012;2:109

11. 11. Rohlfing CL, Wiedmeyer HM, Little RR, England JD, Tennill A, Goldstein DE. Defining the relationship between plasma glucose and $\mathrm{HbA} 1 \mathrm{c}$, Analysis of glucose profiles and $\mathrm{HbA1c}$ in the Diabetes Control and Complications Trial. Diabetes Care 2002;25: 275-78

12. Mendoza SA, Tune BM. Treatment of nephrotic syndrome. J Am Soc Nephrol 1987;3: 889-94

13. Rimsza ME. Complications of corticosteroid therapy. Am J Dis Child 1978;132: 806-10

14. Balaurugan R, Shelveraj N, Bobby Z, Sathiyapriya V. Increased glycated hemoglobion level in non diabetic nephrotic children is associated with oxidative stress. Indian J Physol Pharmacol 2007;51()2:153-159

15. Yucel O, Eker Y, Nuhoglu C, Ceran O. Hemoglobin A1C Levels in Children with Asthma. Indian Pediatrics, 2009; 46:300-303 